\title{
Review Article \\ Optimal Vitamin D Supplementation Levels for Cardiovascular Disease Protection
}

\author{
Sebastian T. Lugg, Phillip A. Howells, and David R. Thickett \\ School of Clinical and Experimental Medicine, College of Medical and Dental Sciences, Centre for Translational Inflammation \\ Research (CTIR), University of Birmingham Laboratories, Queen Elizabeth Hospital Birmingham, Birmingham B15 2TH, UK
}

Correspondence should be addressed to David R. Thickett; d.thickett@bham.ac.uk

Received 14 June 2015; Accepted 9 August 2015

Academic Editor: Silvia Persichilli

Copyright (C) 2015 Sebastian T. Lugg et al. This is an open access article distributed under the Creative Commons Attribution License, which permits unrestricted use, distribution, and reproduction in any medium, provided the original work is properly cited.

\begin{abstract}
First described in relation to musculoskeletal disease, there is accumulating data to suggest that vitamin D may play an important role in cardiovascular disease (CVD). In this review we aim to provide an overview of the role of vitamin $\mathrm{D}$ status as both a marker of and potentially causative agent of hypertension, coronary artery disease, heart failure, atrial fibrillation, stroke, and peripheral vascular disease. The role of vitamin $\mathrm{D}$ levels as a disease marker for all-cause mortality is also discussed. We review the current knowledge gathered from experimental studies, observational studies, randomised controlled trials, and subsequent systematic reviews in order to suggest the optimal vitamin D level for CVD protection.
\end{abstract}

\section{Vitamin D Introduction}

Vitamin D is a fat-soluble vitamin that functions as a steroid hormone. In the skin, ultraviolet (UV) light causes photochemical cleavage of 7-dehydrocholesterol into previtamin D3, which spontaneously isomerises to form vitamin D3 (cholecalciferol) [1] (vitamin D metabolism is demonstrated in Figure 1). Vitamin D2 (ergocalciferol) is a plant-derived form of vitamin D through exposure of yeast to UV light. Skin synthesis of vitamin D3 accounts for about $80 \%$ of vitamin D [2]; dietary sources include fish oils, egg yolks, mushrooms, dairy products, and fortified cereals.

\section{Vitamin D Metabolism and Physiology}

The inactive vitamin D precursors undergo first 25-hydroxylation in the liver to form 25-hydroxyvitamin D [25(OH)D]. This is the main circulating form of vitamin $\mathrm{D}$ and therefore is usually considered as a circulating biomarker for vitamin $\mathrm{D}$ status [3]. The vast majority ( $>99.95 \%)$ of $25(\mathrm{OH}) \mathrm{D}$ is bound to serum proteins and has a half-life of 2 to 3 weeks. The second step is further hydroxylation by $1-\alpha$-hydroxylase in the kidney resulting in 1,25-dihydroxyvitamin $\mathrm{D}$ [1,25(OH)2D] or calcitriol. 1- $\alpha$-hydroxylase activity is modulated by parathyroid hormone (PTH) and fibroblast growth factor 23 .
Various other tissues also express 1- $\alpha$-hydroxylase (e.g., endothelial cells, cardiomyocytes, and macrophages). Furthermore, all target cells express 24-hydroxylase that converts calcitriol into an inactive form $1,24(\mathrm{OH}) 2 \mathrm{D}$. Because of calcitriol's short circulating half-life of only a few hours, it is a less suitable vitamin $\mathrm{D}$ status biomarker.

Most biological effects of vitamin D are likely to be mediated by calcitriol, whether produced locally in tissues or diffusing from the blood. The vitamin D receptor (VDR) has been found in many target tissues includes all the major cardiovascular cell types: endothelial cells [4], vascular smooth muscle (VSM) cells [5], cardiomyocytes [6], platelets [7], and most immune cells [8]. Gene expression is dependent on tissue specific coactivators and cosuppressors [9]. It is estimated that the VDR activation may regulate about $5 \%$ of the total genome [10], pathway analysis suggesting effects upon regulation of cell proliferation, differentiation, apoptosis, oxidative stress, membrane transport, matrix homeostasis, tissue mineralization, and cell adhesion [11].

\section{Vitamin D Deficiency}

A key role of calcitriol is to increase the intestinal absorption of both calcium and phosphorus. The hallmark of vitamin D deficiency is elevated PTH levels; a hormone stimulated as 


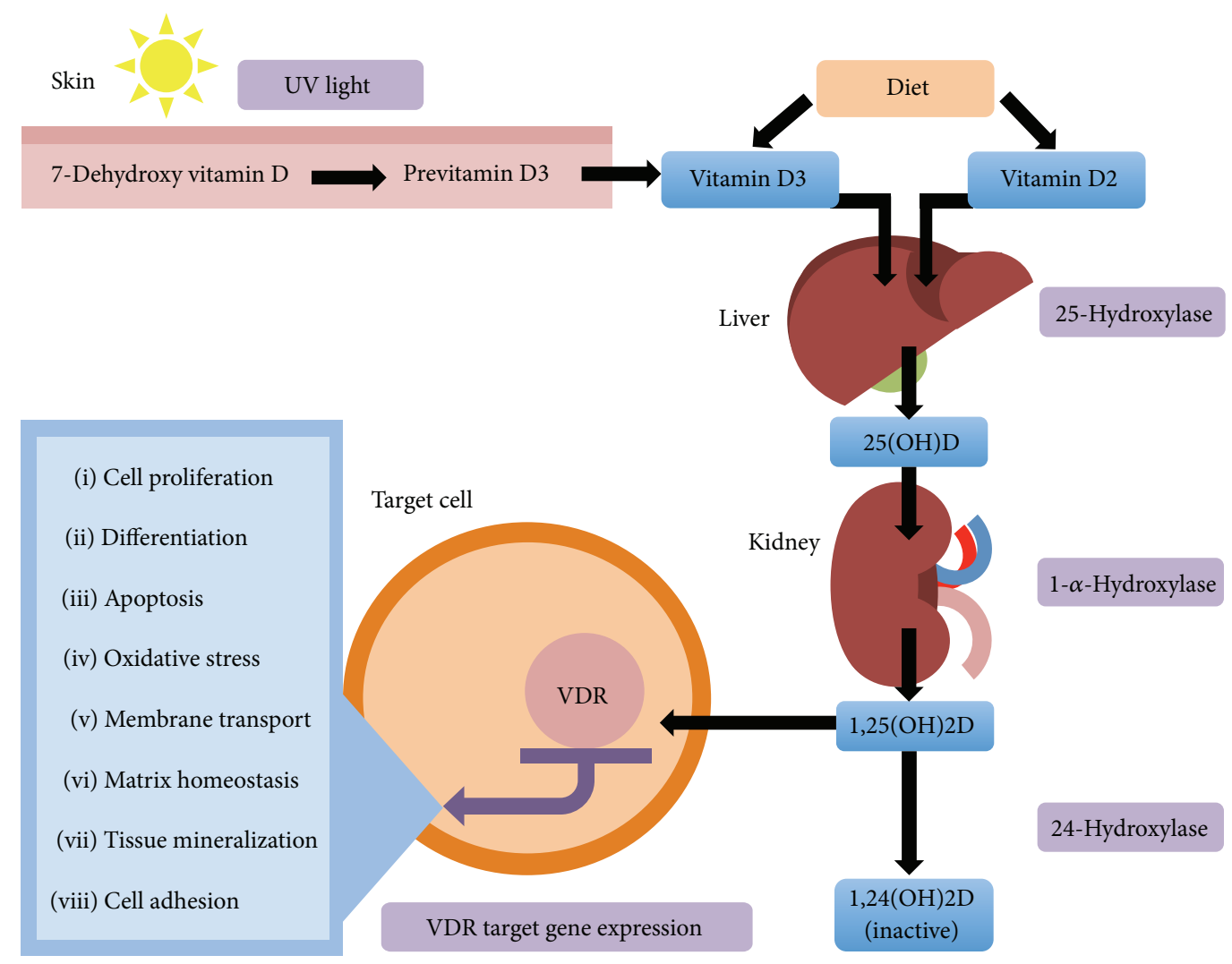

FIGURE 1: Vitamin D metabolism and the vitamin D receptor.

a result of low serum calcium levels. PTH causes increased intestinal and renal calcitriol production, calcium to be extruded from bone, and renal calcium retention. PTH is known to have direct adverse cardiac effects, including endothelial dysfunction, hypertension, increased aortic stiffness, dyslipidemia, hyperglycemia, and subclinical aortic valve calcification. Furthermore, elevated PTH is associated with increased cardiac deaths [12]. Classical clinical consequences of vitamin D deficiency include proximal myopathy and myalgia, which may in part explain the increased risk of functional limitations: falling and fractures in elderly patients who are vitamin D deficient [13-15].

Vitamin D's effect on calcium homeostasis and the level necessary to avoid a rise in PTH levels are commonly used for the definition of adequate vitamin $\mathrm{D}$ status, which is quoted as $\geq 100 \mathrm{nmol} / \mathrm{L}$ ( $40 \mathrm{ng} / \mathrm{mL})$ [16]. Therefore, serum 25(OH)D levels between 100 and $150 \mathrm{nmol} / \mathrm{L}$ are ideal, levels below $50 \mathrm{nmol} / \mathrm{L}$ are associated with severe vitamin $\mathrm{D}$ deficiency, and levels between 50 and $74 \mathrm{nmol} / \mathrm{L}$ are described as moderate vitamin D deficiency or insufficiency [17] (Table 1). Vitamin D toxicity, however, would only be expected at levels $>375 \mathrm{nmol} / \mathrm{L}$ [18]. A review for the UK Government suggested a safe upper limit with low risk of toxicity for most adults at approximately 25-50 micrograms/day (1000$2000 \mathrm{IU} / \mathrm{d})$, with references to sources suggesting much higher doses may be acceptably safe [19].
TABLE 1: Proposed classification of vitamin D status.

\begin{tabular}{lcc}
\hline Vitamin D status & $\mathrm{nmol} / \mathrm{L}$ & $\mathrm{ng} / \mathrm{mL}$ \\
\hline Toxicity & $>375$ & $>150$ \\
Optimal & $100-150$ & $40-60$ \\
Sufficient & $75-99$ & $30-39$ \\
Insufficient & $50-74$ & $20-29$ \\
Deficient & $<50$ & $<20$ \\
\hline
\end{tabular}

Vitamin D insufficiency is prevalent in almost half of the healthy population of developed countries [17]. Risk factors for low 25(OH)D levels are advanced age, female sex, darker skin pigmentation, less sunlight exposure (due to latitude, clothing, or prolonged periods indoors), reduced intake of vitamin D through diet, and the winter season [20].

\section{Vitamin D and Hypertension}

There are many potential mechanisms for vitamin D deficiency to produce hypertension. Direct effects are mediated via the renin-angiotensin system (RAS) or endothelial or VSM function. Indirect effects may include increased occurrence of diabetes mellitus, atherosclerosis, vascular calcification, and changes in renal structure and function [21].

The NHANES III study looked at serum 25(OH)D levels in relation to CVD risk factors in approximately 13,000 US 
adults and found vitamin D status was inversely associated with blood pressure. The authors estimated that about $50 \%$ of the difference in prevalence of hypertension between African and Caucasian Americans was due to vitamin D deficiency in African Americans [22] (key studies of vitamin D and CVD are summarised in Table 2). Other studies found $4 \mathrm{mmHg}$ difference in systolic blood pressure between quartiles [23]. Blood pressure rises and falls with seasonal variation of sunlight, and 25(OH)D levels are inversely related to this [24]. Furthermore, blood pressure rises by $2.5 \mathrm{mmHg}$ for each 10 degrees north or south of the equator [25], which may imply a dose dependent relationship.

A systematic review and meta-analysis investigated whether supplementation with vitamin D or its analogues reduce blood pressure; only randomised controlled trials (RCTs) comparing placebo to vitamin D supplementation for a minimum of 4 weeks were included [26]. This included 46 trials (4541 participants) in the trial-level meta-analysis. No effect of vitamin D supplementation was seen on systolic blood pressure $(0.0$ [ $95 \% \mathrm{CI},-0.8$ to 0.8 ] $\mathrm{mmHg} ; P=0.97)$ or diastolic blood pressure $(-0.1$ [ $95 \% \mathrm{CI},-0.6$ to 0.5$] \mathrm{mmHg}$; $P=0.84)$. Furthermore, similar results were found on the analysis of individual patient data obtained for 27 trials (3092 participants). The investigators found that subgroup analysis did not reveal any baseline factor predictive of a better response to therapy.

People of African-Caribbean ethnicity have significantly higher rates of hypertension than Caucasian people, which may be due to the higher skin content of melanin reducing vitamin D3 production. A recently published 4 -arm placebo controlled RCT investigated the effect of supplementation of 1000, 2000, and $4000 \mathrm{IU}$ of vitamin D3 per day on blood pressure in an unselected population of people of African-Caribbean ethnicity [27]. At 3 months, there was a statistically significant reduction of $1.4 \mathrm{mmHg}$ in the systolic blood pressure of participants for each additional $1000 \mathrm{IU} / \mathrm{d}$ of vitamin $\mathrm{D}$ supplementation $(P=0.04)(-1.4 \mathrm{mmHg}$ for placebo versus $4.0 \mathrm{mmHg}$ for $4000 \mathrm{IU} / \mathrm{d}$ ), whilst there was no significant reduction in the diastolic blood pressure $(P=$ 0.37). Another study in African-Caribbean youths found supplementing $2000 \mathrm{IU} / \mathrm{d}$ may be effective at optimising vitamin D status and reducing aortic stiffness [28].

Overall, blood pressure changes in response to changes in serum $25(\mathrm{OH}) \mathrm{D}$ levels are detected inconsistently and are small when detected, thus not reaching clinical significance, although this may reflect the baseline characteristics, study duration, or differing dosage. Further research is needed in this field. Of interest will be the future data from the DOHEALTH study [29], a large randomised clinical trial $(n=$ 2158) sponsored by the European Union, which aims to establish whether $2000 \mathrm{IU} / \mathrm{d}$ vitamin D, omega-3 fatty acids, and a simple home exercise program will prevent disease at older age, including blood pressure among other parameters as a primary endpoint.

\section{Vitamin D and Heart Failure}

There is increasing evidence that vitamin D has modulatory effects on mechanisms known to be important in heart failure
(HF). Animal models have shown that calcitriol has been shown to have a key role in enabling the maturation and differentiation of ventricular myocytes isolated from neonatal rat hearts [30] and VDR knockout mice exhibit increased ventricular mass and higher levels of atrial natriuretic peptide, which lead to ventricular dilatation and impaired electromechanical association [31-33].

In observational studies, the incidence of chronic $\mathrm{HF}$ has been shown to be greater in cohorts with low vitamin D status [34]. However, the ICELAND-MI study looking at an older-aged community cohort showed no association between serum $25(\mathrm{OH}) \mathrm{D}$ and magnetic resonance imaging measures of cardiac function, whereas elevated PTH was associated with lower ejection fraction and increased left ventricular mass [35]. Other studies have shown elevated PTH to be associated with HF [36], and left ventricular hypertrophy [37], possibly suggesting vitamin D deficiency, may be a marker of elevated PTH levels.

An RCT of 80 infants with chronic congestive HF investigated the effects of 12 weeks of vitamin D (1000 IU) versus placebo on cardiac function. The baseline $25(\mathrm{OH}) \mathrm{D}$ levels were low; $25(\mathrm{OH}) \mathrm{D}$ levels significantly rose in the intervention group and were associated with both improvement in cardiac function and a marked increase in interleukin- (IL-) 10 and decreased PTH, IL-6, and TNF- $\alpha$ [38]. In adults with $\mathrm{HF}$, a RCT of placebo verses vitamin $\mathrm{D}$ supplementation for 9 months was associated with a $67 \mathrm{nmol} / \mathrm{L}$ rise in $25(\mathrm{OH}) \mathrm{D}$ levels; there were significantly reduced levels of proinflammatory cytokines TNF- $\alpha$, IL-10, and PTH in the treatment group compared to placebo [39]. Vitamin D deficiency not only is more common in HF compared to non-HF controls $25(\mathrm{OH}) \mathrm{D}<25 \mathrm{nmol} / \mathrm{L}$ (28\% versus $22 \%$ ) but also has been shown to be an independent predictor for increased mortality in HF patients (hazard ratio [HR] 1.52; 95\% CI, 1.21-1.92), and supplementation has been shown to offer survival benefit from a retrospective database analysis ( $\mathrm{HR}, 0.68 ; 95 \% \mathrm{CI}$, 0.54-0.85; $P<0.0001)$ [40].

\section{Vitamin D and Atrial Fibrillation}

Vitamin D may play a role in pathogenesis of atrial fibrillation (AF). Proposed mechanisms include the indirect effect of vitamin $\mathrm{D}$ on the atria through RAS and modulation in levels of reactive oxygen species, which contribute to inflammation and proarrhythmic substrate formation [41]. Large observational studies find the incidence of AF to be higher in winter than in summer months $[42,43]$, correlating with seasonal variation in $25(\mathrm{OH}) \mathrm{D}$ levels. However, this does not imply causality, since the lower winter temperature and the higher incidence of respiratory tract infections are risk factors for AF. The Framingham Heart Study showed no association between $25(\mathrm{OH}) \mathrm{D}$ levels and AF in either original or offspring cohorts [44] and no association has been demonstrated between 25(OH)D levels and different types of AF (either paroxysmal, persistent, or permanent) [45]. Other studies have shown significantly lower $25(\mathrm{OH}) \mathrm{D}$ levels in patients with nonvalvular AF [46]; those with levels $<50 \mathrm{nmol} / \mathrm{L}$ have a twofold higher incidence of nonvalvular 
TABLE 2: Key studies in vitamin D and cardiovascular disease.

\begin{tabular}{|c|c|c|c|c|}
\hline Disease & Study & Design & $\begin{array}{l}\text { Number of } \\
\text { participants }\end{array}$ & Outcome \\
\hline \multirow{4}{*}{ Hypertension } & $\begin{array}{l}\text { Scragg et al. (2007) } \\
{[22]}\end{array}$ & $\begin{array}{l}\text { Cross-sectional, } \\
\text { observational }\end{array}$ & 12,644 & Vitamin D status is inversely associated with BP. \\
\hline & $\begin{array}{l}\text { Beveridge et al. (2015) } \\
{[26]}\end{array}$ & $\begin{array}{l}\text { Meta-analysis of } \\
46 \text { RCTs }\end{array}$ & 4541 & $\begin{array}{l}\text { No effect of Vitamin D supplementation on } \\
\text { systolic or diastolic BP. }\end{array}$ \\
\hline & $\begin{array}{l}\text { Forman et al. (2013) } \\
\text { [27] }\end{array}$ & RCT & 283 & Dose dependent reduction in systolic BP. \\
\hline & $\begin{array}{l}\text { Dong et al. (2010) } \\
{[28]}\end{array}$ & RCT & 49 & $\begin{array}{l}\text { Reduction in arterial stiffness in young } \\
\text { African-Caribbean subjects. }\end{array}$ \\
\hline \multirow{7}{*}{ Heart failure } & $\begin{array}{l}\text { Zittermann et al. } \\
(2003) \\
{[34]}\end{array}$ & Observational & 88 & $\begin{array}{l}\text { Chronic heart failure is more common in groups } \\
\text { with low vitamin } \mathrm{D} \text {. }\end{array}$ \\
\hline & $\begin{array}{l}\text { van Ballegooijen et al. } \\
(2013) \\
{[35]}\end{array}$ & $\begin{array}{l}\text { Cross-Sectional, } \\
\text { observational }\end{array}$ & 969 & $\begin{array}{l}\text { Higher PTH was associated with greater left } \\
\text { ventricular mass and lower systolic function. }\end{array}$ \\
\hline & $\begin{array}{l}\text { Kestenbaum et al. } \\
(2011) \\
{[36]}\end{array}$ & Observational & 2,312 & $\begin{array}{l}\text { Vitamin D deficiency is associated with MI, } \\
\text { mortality, and excess PTH with heart failure. }\end{array}$ \\
\hline & $\begin{array}{l}\text { Saleh et al. (2003) } \\
\text { [37] }\end{array}$ & Observational & 2,700 & PTH is associated with left ventricular mass. \\
\hline & $\begin{array}{l}\text { Shedeed (2012) } \\
{[38]}\end{array}$ & RCT & 80 & $\begin{array}{l}\text { Supplementation improved cardiac function and } \\
\text { decreased PTH and inflammatory markers. }\end{array}$ \\
\hline & $\begin{array}{l}\text { Schleithoff et al. } \\
(2006) \\
{[39]}\end{array}$ & $\mathrm{RCT}$ & 93 & $\begin{array}{l}\text { Supplementation reduced inflammatory } \\
\text { mediators and parathyroid hormone. }\end{array}$ \\
\hline & $\begin{array}{l}\text { Gotsman et al. (2012) } \\
{[40]}\end{array}$ & Observational & 49,834 & $\begin{array}{l}\text { Vitamin D deficiency highly prevalent and } \\
\text { predictive of reduced survival. }\end{array}$ \\
\hline \multirow{7}{*}{ Atrial fibrillation } & $\begin{array}{l}\text { Frost et al. (2002) } \\
{[42]}\end{array}$ & $\begin{array}{l}\text { Retrospective, } \\
\text { observational }\end{array}$ & 32,992 & $\begin{array}{l}\text { Seasonal variation in } \mathrm{AF} \text { incidence, showing a } \\
\text { winter peak and summer trough. }\end{array}$ \\
\hline & $\begin{array}{l}\text { Murphy et al. (2004) } \\
\text { [43] }\end{array}$ & $\begin{array}{l}\text { Retrospective, } \\
\text { observational }\end{array}$ & 68,045 & $\begin{array}{l}\text { Winter peak of hospitalizations with AF, with } \\
\text { higher winter mortality. }\end{array}$ \\
\hline & $\begin{array}{l}\text { Reinstra et al. (2011) } \\
{[44]}\end{array}$ & $\begin{array}{l}\text { Retrospective, } \\
\text { observational }\end{array}$ & 2,930 & Vitamin D is not associated with AF. \\
\hline & $\begin{array}{l}\text { Qayyum et al. (2012) } \\
\text { [45] }\end{array}$ & Observational & 258 & Vitamin D is not associated with AF, stroke, or MI. \\
\hline & $\begin{array}{l}\text { Demir et al. (2014) } \\
{[46]}\end{array}$ & Case-control & 298 & Vitamin D is associated with nonvalvular AF. \\
\hline & $\begin{array}{l}\text { Chen et al. (2014) } \\
\text { [47] }\end{array}$ & Case-control & 162 & $\begin{array}{l}\text { Association with AF and vitamin D deficiency are } \\
\text { shown. }\end{array}$ \\
\hline & $\begin{array}{l}\text { Ozcan et al. (2015) } \\
{[48]}\end{array}$ & Case-control & 227 & $\begin{array}{l}\text { Vitamin D deficiency was associated with } \\
\text { new-onset AF. }\end{array}$ \\
\hline \multirow{5}{*}{$\begin{array}{l}\text { Coronary artery } \\
\text { disease }\end{array}$} & $\begin{array}{l}\text { Thomas et al. (2012) } \\
\text { [50] }\end{array}$ & Cohort & 1,801 & $\begin{array}{l}\text { Reduced all-cause and cardiovascular mortality } \\
\text { and heart failure but not MI. }\end{array}$ \\
\hline & $\begin{array}{l}\text { Wang et al. (2008) } \\
\text { [51] }\end{array}$ & Cohort & 1,739 & $\begin{array}{c}\text { Higher risk of cardiovascular events with lower } \\
\text { vitamin D levels. }\end{array}$ \\
\hline & $\begin{array}{l}\text { Oz et al. (2013) } \\
{[52]}\end{array}$ & $\begin{array}{l}\text { Cross-sectional, } \\
\text { observational }\end{array}$ & 222 & $\begin{array}{l}\text { Vitamin D deficiency associated with slow } \\
\text { coronary flow, endothelial dysfunction, and } \\
\text { subclinical atherosclerosis. }\end{array}$ \\
\hline & $\begin{array}{l}\text { Liew et al. (2015) } \\
{[53]}\end{array}$ & Observational & 375 & $\begin{array}{l}\text { Low vitamin D associated with worse } \\
\text { angiographic CAD, nonarterial stiffness, or PVD. }\end{array}$ \\
\hline & Ford et al. (2014) [54] & RCT & 5,292 & $\begin{array}{l}\text { Vitamin D is protective against heart failure but } \\
\text { not MI and stroke. }\end{array}$ \\
\hline
\end{tabular}


TABLE 2: Continued.

\begin{tabular}{|c|c|c|c|c|}
\hline Disease & Study & Design & $\begin{array}{l}\text { Number of } \\
\text { participants }\end{array}$ & Outcome \\
\hline \multirow{4}{*}{ Stroke } & $\begin{array}{l}\text { Witham et al. (2012) } \\
\text { [59] }\end{array}$ & $\mathrm{RCT}$ & 58 & $\begin{array}{l}\text { High dose of vitamin D improved endothelial } \\
\text { function in stroke patients with controlled BP. }\end{array}$ \\
\hline & $\begin{array}{l}\text { Hsia et al. }(2007) \\
{[60]}\end{array}$ & RCT & 36,282 & No observed changes in coronary or stroke risk. \\
\hline & $\begin{array}{l}\text { Avenell et al. (2012) } \\
{[61]}\end{array}$ & RCT & 5,292 & $\begin{array}{l}\text { No effect on mortality, vascular disease, cancer } \\
\text { mortality, or cancer incidence. }\end{array}$ \\
\hline & $\begin{array}{l}\text { Trivedi et al. (2003) } \\
{[62]}\end{array}$ & $\mathrm{RCT}$ & 2,686 & $\begin{array}{c}\text { Fractures may be reduced by supplementation but } \\
\text { no change in stroke risk. }\end{array}$ \\
\hline \multirow{4}{*}{$\begin{array}{l}\text { Peripheral vascular } \\
\text { disease }\end{array}$} & $\begin{array}{l}\text { Anderson et al. (2010) } \\
{[63]}\end{array}$ & $\begin{array}{l}\text { Retrospective, } \\
\text { observational }\end{array}$ & 41,504 & $\begin{array}{l}\text { Vitamin D deficiency associated with diabetes, } \\
\text { hyperlipidemia, HTN, CAD, PVD, MI, and stroke. }\end{array}$ \\
\hline & $\begin{array}{l}\text { Melamed et al. (2008) } \\
{[64]}\end{array}$ & $\begin{array}{l}\text { Retrospective, } \\
\text { observational }\end{array}$ & 4,839 & Low vitamin D is associated with higher PVD. \\
\hline & $\begin{array}{l}\text { Fahrleitner et al. } \\
(2002) \\
{[65]}\end{array}$ & $\begin{array}{l}\text { Cross-sectional, } \\
\text { observational }\end{array}$ & 327 & $\begin{array}{c}\text { PVD is associated with vitamin D deficiency, } \\
\text { secondary hyperparathyroidism, and } \\
\text { osteomalacia. }\end{array}$ \\
\hline & $\begin{array}{l}\text { McDermott et al. } \\
(2014) \\
{[67]}\end{array}$ & Observational & 658 & $\begin{array}{l}\text { Lower vitamin D levels associated with faster } \\
\text { decline in walking in those with PVD. }\end{array}$ \\
\hline \multirow{5}{*}{ Mortality } & $\begin{array}{l}\text { Zittermann et al. } \\
(2012) \\
{[68]}\end{array}$ & $\begin{array}{l}\text { Meta-analysis of } \\
\text { prospective } \\
\text { cohorts }\end{array}$ & 62,548 & $\begin{array}{c}\text { Nonlinear decrease in mortality for increased } \\
\text { vitamin D levels, plateauing around } 87.5 \mathrm{nmol} / \mathrm{L} \text {. }\end{array}$ \\
\hline & $\begin{array}{l}\text { Johansson et al. (2012) } \\
\text { [69] }\end{array}$ & Observational & 2,878 & $\begin{array}{l}\text { In elderly men, low vitamin D levels are } \\
\text { associated with increased mortality. }\end{array}$ \\
\hline & $\begin{array}{l}\text { Elamin et al. (2011) } \\
\text { [70] }\end{array}$ & $\begin{array}{l}\text { Meta-analysis of } \\
51 \text { RCTs }\end{array}$ & $51 \mathrm{RCTs}$ & $\begin{array}{l}\text { No evidence of significant reduction in mortality } \\
\text { or cardiovascular risk. }\end{array}$ \\
\hline & $\begin{array}{l}\text { Rejnmark et al. (2012) } \\
\text { [71] }\end{array}$ & $\begin{array}{l}\text { Meta-analysis of } \\
8 \text { major trials }\end{array}$ & 70,528 & Vitamin D with calcium reduced overall mortality. \\
\hline & $\begin{array}{l}\text { Bjelakovic et al. (2014) } \\
{[72]}\end{array}$ & $\begin{array}{l}\text { Meta-analysis of } \\
56 \text { RCTs }\end{array}$ & 95,286 & $\begin{array}{c}\text { Vitamin D3 seemed to decrease mortality in } \\
\text { elderly people. }\end{array}$ \\
\hline
\end{tabular}

BP, blood pressure; PTH, parathyroid hormone; AF, atrial fibrillation; MI, myocardial infarction; CAD, coronary artery disease; PVD, peripheral vascular disease; HTN, hypertension; RCT, randomised controlled trial.

AF than those with levels $>75 \mathrm{nmol} / \mathrm{L}$ [47]. Another observational study showed vitamin $\mathrm{D}$ deficiency to be associated with new-onset AF in a hypertensive cohort [48].

\section{Vitamin D and Coronary Artery Disease}

Vitamin D exerts a variety of direct effects relating to atherosclerosis such as modulating endothelial function and influencing VSM proliferation and migration; indirect effects occur through dysglycemia, dyslipidemia, and RAS [49]. In the LURIC Study, a large cohort of subjects $(n=1801)$ referred for coronary angiography found $92 \%$ of individuals had suboptimal $25(\mathrm{OH}) \mathrm{D}$ levels $(<75 \mathrm{nmol} / \mathrm{L})$ and $22 \%$ were severely deficient $(<25 \mathrm{nmol} / \mathrm{L})$ [50]. Furthermore, after adjustment, those patients with optimal levels showed a substantial reduction in all-cause mortality (HR, 0.25; 95\% CI, 0.13-0.46) and cardiovascular mortality compared to those with severe deficiency. The Framingham Offspring Study found that individuals with $25(\mathrm{OH}) \mathrm{D}<37.5 \mathrm{nmol} / \mathrm{L}$ had a hazard ratio of 1.62 for development of CVD compared to those with a level of $\geq 37 \mathrm{nmol} / \mathrm{L}$ [51].
An intriguing cross-sectional and observational study looked at the effect of $25(\mathrm{OH}) \mathrm{D}$ levels $<75 \mathrm{nmol} / \mathrm{L}$ on epicardial coronary flow rate, subclinical atherosclerosis, and endothelial function. The study enrolled 222 patients who had undergone coronary angiography for suspected ischemic heart disease and were found to have normal or near-normal coronary arteries. The incidence of slow coronary flow rate (SCF) was significantly higher in the vitamin $\mathrm{D}$ deficient group (relative risk [RR], 3.5; 95\% CI, 1.1-10.5; $P=0.01$ ) and after adjusting for cardiovascular disease risk factors vitamin $\mathrm{D}$ insufficiency was an independent risk factor for SCF. In addition, vitamin D insufficiency was associated with endothelial dysfunction and subclinical atherosclerosis [52]. Furthermore, in a study of 375 patients undergoing coronary angiography to assess the severity of coronary artery disease (CAD), levels of $25(\mathrm{OH}) \mathrm{D}$ were significantly lower in patients with CAD than in those without $(57 \pm 1.73$ versus $70.1 \pm$ $2.46 \mathrm{nmol} / \mathrm{L} ; P<0.01$ ) [53]. The authors found vitamin $\mathrm{D}$ to be the most significant predictor for CAD and $25(\mathrm{OH}) \mathrm{D}$ levels were significantly lower in triple vessel compared to single vessel disease. However, there was no correlation between $25(\mathrm{OH}) \mathrm{D}$ levels and arterial stiffness using pulse 
wave velocity and peripheral artery disease using ankle brachial pressure index.

In assessing supplementation of vitamin $\mathrm{D}$, the RECORD trial $(n=5292)$ was a factorial RCT that compared the effects of vitamin D3 $(800 \mathrm{IU} / \mathrm{d})$, calcium, vitamin D plus calcium, and placebo in cardiovascular events. The study found that vitamin $\mathrm{D}$ might protect against heart failure (HR, 0.75; 95\% CI, 0.58-0.97) but does not appear to protect against myocardial infarction (MI) and stroke. The authors conducted further a systematic review and meta-analysis including 21 studies $(n=13,033)$, which reached the same conclusion [54]. Another meta-analysis of 51 RCTs found that vitamin D supplementation did not have a significant impact on MI (RR, 1.02; 95\% CI, 0.93-1.13; $P=0.64$ ) [55]. There is currently insufficient evidence that vitamin D supplementation is associated with CAD risk reduction.

\section{Vitamin D and Stroke}

There have been a number of observational studies linking vitamin $\mathrm{D}$ status with stroke as well as plausible animal data and imaging studies of carotid atheroma. The VDR in the brain modulates neuronal activity as well as potentially influencing vascular effects [56]. Elevated PTH has been associated with stroke as well as adverse cardiovascular outcomes [57]. An observational study from Denmark, which also included a meta-analysis, showed stepwise increase in stroke incidence for decreasing 25(OH)D level quartiles [58].

In order to test the hypothesis that supplementation may be beneficial, a group of people with previous strokes were given 10,000 IU of vitamin D2 or placebo. At 8 weeks, endothelial function was shown to improve using brachial artery ultrasound following an occlusion test, although other markers of cardiovascular health were not. The small numbers $(n=58)$, age of the cohort, and modest increase in vitamin D levels may be factors in the limited positive findings. The authors recommend a more nuanced approach to vitamin D supplementation than blanket delivery [59].

The very large Women's Health Initiative study [60] showed no significant difference in stroke with treatment (calcium and $200 \mathrm{IU}$ vitamin D3 twice daily) versus placebo. However, this trial was not powered for cardiovascular endpoints, the inclusion of calcium supplementation may have counteracted the benefits of vitamin $\mathrm{D}$, and vitamin $\mathrm{D}$ dose may have been too small [57]. Another RCT demonstrated that supplementation of vitamin D3 (800 IU) with/without calcium versus placebo was shown not to alter outcome for stroke or cardiovascular mortality [61]. Interestingly, an RCT using 10,000 IU delivered every 4 months was conducted which showed lower fracture rates and a nonsignificant trend to reduced mortality and cardiovascular events [62]. It has been suggested that lack of PTH sampling in RCTs makes it more difficult to ascertain adequate dosing [57].

Overall, the association between low vitamin D and stroke is clear but its causality is less clear and there has been a lack of benefit of supplementation demonstrated from clinical trials to date.

\section{Vitamin D and Peripheral Vascular Disease}

Observational studies suggest a role of vitamin $\mathrm{D}$ status in peripheral vascular disease (PVD); a retrospective database study from the US showed a 50\% increase in PVD in the lowest tertile of $25(\mathrm{OH}) \mathrm{D}$ levels $(<37.5 \mathrm{nmol} / \mathrm{L})$ compared to the higher two tertiles [63]. Similarly, the data from the NHANES Study showed that after adjusting for risk factors those patients in the lowest quartile $(<44.5 \mathrm{nmol} / \mathrm{L})$ were 1.80 (CI 1.19-2.74) times more likely to have PVD compared to the highest quartile $(>73 \mathrm{nmol} / \mathrm{L})$ [64]. The study found no association between PVD and calcium, phosphate, and PTH. An older study demonstrated worsening PVD was associated with lower $25(\mathrm{OH}) \mathrm{D}$ levels but suggested that it could be that limited exercise and sunlight exposure from reduced mobility secondary to PVD that led to hypovitaminosis D rather than vitamin $\mathrm{D}$ deficiency being the cause or exacerbating factor in PVD [65].

Vitamin D may act to promote PVD by exacerbating traditional cardiovascular risk factors via mechanisms described above or by promoting myopathy, in turn limiting exercise and/or contributing to coexisting symptoms [66]. Alternatively, vitamin D may play a role in the pathobiology of atherosclerosis as in other vascular beds [67].

A detailed investigation of the elderly and vitamin $\mathrm{D}$ showed that those with PVD and low 25(OH)D $(<75 \mathrm{nmol} / \mathrm{L})$ had a faster decline in their 6-minute walk test over follow-up and also a faster decline in their Short Physical Performance Battery (a score for assessing physical capability in older adults), compared to those with higher 25(OH)D levels. In addition, calf muscle cross-sectional area loss was also greater. Vitamin D deficient patients without PVD had faster declines in walking velocity. There were no associations between $25(\mathrm{OH}) \mathrm{D}$ levels and mortality, although the total number of deaths was relatively small $(n=93)$ [67].

\section{Vitamin $D$ and Overall Mortality}

Most observational studies have associated a low vitamin D status with an increased risk of death $[68,69]$. A number of RCTs have investigated the effect of pharmacological supplementation of vitamin $\mathrm{D}$ and subsequent risk of overall mortality. In a meta-analysis of 51 RCTs vitamin D supplementation did not have a significant impact on mortality (RR, 0.96\%; 95\% CI, 0.93-1.00; $P=0.08$ ) [70]. There is evidence that supplementation with vitamin $\mathrm{D}$ combined with calcium but not vitamin D alone may improve overall mortality. An individual patient meta-analysis of eight major vitamin $\mathrm{D}$ trials including 70,528 patients $(86.8 \%$ females with median age of 70) found vitamin $\mathrm{D}$ alone did not affect mortality but when supplemented with calcium this reduced mortality by $7 \%$ (HR, $0.91 ; 95 \% \mathrm{CI}, 0.84-0.98)$ [71]. The authors calculated that the number needed to treat with vitamin D plus calcium was 151 for 3 years to prevent 1 death. Unfortunately, baseline vitamin $\mathrm{D}$ levels were not performed on these patients. Clearly, whether vitamin D supplementation provides a mortality benefit with or without calcium supplements is a very important issue for future research. 
TABLE 3: Recommended daily vitamin D supplementation for adults.

\begin{tabular}{|c|c|c|}
\hline Body & Recommendation & Daily dose \\
\hline \multirow{3}{*}{ Institute of Medicine [74] } & Supplementation for age groups & \\
\hline & (i) Individuals up to 70 years old & $600 \mathrm{IU}$ \\
\hline & (ii) Older individuals ( $>70$ years old) & $800 \mathrm{IU}$ \\
\hline $\begin{array}{l}\text { National Institute for Health and Care } \\
\text { Excellence }[80] \text { and Public Health } \\
\text { England [76] }\end{array}$ & $\begin{array}{l}\text { Supplementation for at risk groups } \\
\text { (i) Pregnant and breastfeeding women, particularly young women. } \\
\text { (ii) People over } 65 . \\
\text { (iii) People who have low or no exposure to the sun, for example, those who cover } \\
\text { their skin for cultural reasons and who are housebound or confined indoors for } \\
\text { long periods. } \\
\text { (iv) People with darker skin, for example, people of African, African-Caribbean, or } \\
\text { South Asian family origin. }\end{array}$ & $\begin{array}{l}10 \\
\text { micrograms } \\
(400 \mathrm{IU})\end{array}$ \\
\hline
\end{tabular}

IU, international units.

A meta-analysis of 50 RCTs where vitamin D was administered for median of 2 years found vitamin D3 to significantly decrease mortality (RR, 0.94; 95\% CI, 0.91-0.98; 32 trials), whilst vitamin D2, alfacalcidol, and calcitriol had no statistical effect on mortality [72]. Furthermore, trials looking into baseline vitamin D status using cutoffs of above and below $50 \mathrm{nmol} / \mathrm{L}$, dosing above or below $800 \mathrm{IU} / \mathrm{d}$, daily or intermittent dose frequency, and the addition or absence of calcium all had no significant effects on mortality, though this could be due to type II errors. When vitamin D3 was combined with calcium, there was a significant increase in nephrolithiasis (RR, 1.17; 95\% CI, 1.02-1.34; $P=0.02$ ). Furthermore, alfacalcidol and calcitriol increased the risk of hypercalcaemia (RR, 3.18; 95\% CI, 1.17-8.68; $P=0.02$ ). The authors concluded that vitamin D3 seemed to decrease mortality in predominantly elderly women who are not dependent on help or living in institutional care.

Most of the data conducted are on vitamin $\mathrm{D}$ in primary prevention trials; thus it is difficult to draw any conclusions with regard to vitamin $\mathrm{D}$ in secondary prevention because of the lack of evidence currently available. When looking at trial data in primary prevention, there is risk for attrition bias originating from substantial dropout of participants and also outcome reporting bias due to investigators not reporting mortality. Thus, the available information of vitamin D and mortality is inconclusive and therefore further placebo controlled RCTs are needed.

\section{Vitamin D Supplementation Recommendations}

Oral vitamin D3 taken at physiological doses is effective in raising blood $25(\mathrm{OH}) \mathrm{D}$ levels and can be taken daily, weekly, or monthly as it produces comparable increases in $25(\mathrm{OH}) \mathrm{D}$ levels [73]. None of the major cardiology societies have made recommendations for the optimum supplementation for cardiovascular disease. Based on the positive effect for musculoskeletal health, the Institute of Medicine (IOM) in 2011 recommended minimum vitamin D levels of $50 \mathrm{nmol} / \mathrm{L}$ ( $\geq 20 \mathrm{ng} / \mathrm{mL}$ ) [74] (Table 3). Therefore, their guidance for daily vitamin $\mathrm{D}$ intake in the general population is $600 \mathrm{IU} / \mathrm{d}$ for individuals up to 70 years old and $800 \mathrm{IU} / \mathrm{d}$ in the older individuals which corresponded to the recommended daily allowance (covering requirements of $\geq 97.5 \%$ of the general population). The US Endocrine Society suggests $1500-2000 \mathrm{IU} / \mathrm{d}$ of vitamin $\mathrm{D}$ is needed for adults to maintain $25(\mathrm{OH}) \mathrm{D}$ above the optimal level of $75 \mathrm{nmol} / \mathrm{L}$ [75]. In the UK, only at risk groups are recommended for supplementation, at $10 \mathrm{micrograms} /$ day $(400 \mathrm{IU} / \mathrm{d})$, although the categories included are very broad [76]. With regard to safety, both the official statements of the IOM and the European Food Safety Authority declare that daily intakes up to 4000 IU are safe $[74,77]$. Only in exceedingly rare cases, exposure to extraordinarily high pharmacological doses of vitamin D has caused sequelae [78]. Despite this, we should be cautious with high-dose vitamin $\mathrm{D}$ supplementation as there is some suggestion of a J-shaped association between $25(\mathrm{OH}) \mathrm{D}$ levels and mortality [79].

\section{Conclusions}

There are weak signals of benefit of vitamin D supplementation in heart failure, whilst studies have so far shown vitamin $\mathrm{D}$ to be ineffective as an agent in lowering blood pressure and thus it should not be used as an antihypertensive agent. In CAD, AF, PVD, and stroke, although low vitamin D levels are associated with disease occurrence, supplementation has not yet been shown to be of benefit. Whether vitamin D is a causal factor or convenient biomarker is not yet established and maybe supplementation in cohorts of older adults may be too late. Modest reductions in all-cause mortality by vitamin D3 were demonstrated by meta-analysis [71], but the number needed for benefit was around 150 and, due to attrition bias, the reliability of the estimate was low.

On the other hand, vitamin D deficiency is very prevalent and modest improvements might make substantial health gains, with a low risk of adverse outcome. On the strength of current evidence, supplementation for optimum cardiovascular outcomes alone does not seem to be a justifiable position, but, for overall health, following IOM [74] and National Institute for Health and Care (NICE) guidance [80] is the best effort to answer an underinvestigated question. A number of areas, particularly heart failure, warrant controlled 
trials look for robust evidence for a potentially cheap, low risk, and effective treatment option.

\section{Conflict of Interests}

The authors declare that there is no conflict of interests regarding the publication of this paper.

\section{Authors' Contribution}

Sebastian T. Lugg and Phillip A. Howells have been involved in drafting the paper. David R. Thickett has critically reviewed the paper and given final approval of the version to be published. All authors read and approved the final paper.

\section{References}

[1] A. S. Dusso, A. J. Brown, and E. Slatopolsky, "Vitamin D," American Journal of Physiology-Renal Physiology, vol. 289, no. 1, pp. F8-F28, 2005.

[2] H. M. MacDonald, A. Mavroeidi, W. D. Fraser et al., "Sunlight and dietary contributions to the seasonal vitamin D status of cohorts of healthy postmenopausal women living at northerly latitudes: a major cause for concern?" Osteoporosis International, vol. 22, no. 9, pp. 2461-2472, 2011.

[3] M. F. Holick, "Vitamin D status: measurement, interpretation, and clinical application," Annals of Epidemiology, vol. 19, no. 2, pp. 73-78, 2009.

[4] J. Merke, P. Milde, S. Lewicka et al., "Identification and regulation of 1,25-dihydroxyvitamin D3 receptor activity and biosynthesis of 1,25-dihydroxyvitamin D3. Studies in cultured bovine aortic endothelial cells and human dermal capillaries," The Journal of Clinical Investigation, vol. 83, no. 6, pp. 1903-1915, 1989.

[5] D. Somjen, Y. Weisman, F. Kohen et al., "25-Hydroxyvitamin D3-1alpha-hydroxylase is expressed in human vascular smooth muscle cells and is upregulated by parathyroid hormone and estrogenic compounds," Circulation, vol. 111, no. 13, pp. 16661671, 2005.

[6] D. X. Tishkoff, K. A. Nibbelink, K. H. Holmberg, L. Dandu, and R. U. Simpson, "Functional vitamin D receptor (VDR) in the t-tubules of cardiac myocytes: VDR knockout cardiomyocyte contractility," Endocrinology, vol. 149, no. 2, pp. 558-564, 2008.

[7] F. Silvagno, E. De Vivo, A. Attanasio, V. Gallo, G. Mazzucco, and G. Pescarmona, "Mitochondrial localization of vitamin D receptor in human platelets and differentiated megakaryocytes," PLoS ONE, vol. 5, no. 1, Article ID e8670, 2010.

[8] X. Guillot, L. Semerano, N. Saidenberg-Kermanac'h, G. Falgarone, and M.-C. Boissier, "Vitamin D and inflammation," Joint Bone Spine, vol. 77, no. 6, pp. 552-557, 2010.

[9] N. J. McKenna, R. B. Lanz, and B. W. O’Malley, "Nuclear receptor coregulators: cellular and molecular biology," Endocrine Reviews, vol. 20, no. 3, pp. 321-344, 1999.

[10] A. Hossein-nezhad, A. Spira, and M. F. Holick, "Influence of vitamin D status and vitamin D3 supplementation on genome wide expression of white blood cells: a randomized doubleblind clinical trial," PLoS ONE, vol. 8, no. 3, Article ID e58725, 2013.

[11] R. Bouillon, G. Carmeliet, L. Verlinden et al., "Vitamin D and human health: lessons from vitamin D receptor null mice," Endocrine Reviews, vol. 29, no. 6, pp. 726-776, 2008.
[12] A. Tomaschitz, E. Ritz, B. Pieske et al., "Aldosterone and parathyroid hormone interactions as mediators of metabolic and cardiovascular disease," Metabolism: Clinical and Experimental, vol. 63, no. 1, pp. 20-31, 2014.

[13] A. C. Looker and M. E. Mussolino, "Serum 25-hydroxyvitamin D and hip fracture risk in older U.S. white adults," Journal of Bone and Mineral Research, vol. 23, no. 1, pp. 143-150, 2008.

[14] F. R. Pérez-López, "Vitamin D and its implications for musculoskeletal health in women: an update," Maturitas, vol. 58, no. 2, pp. 117-137, 2007.

[15] E. Sohl, N. M. Van Schoor, R. T. de Jongh, M. Visser, D. J. H. Deeg, and P. Lips, "Vitamin d status is associated with functional limitations and functional decline in older individuals," The Journal of Clinical Endocrinology \& Metabolism, vol. 98, no. 9, pp. E1483-E1490, 2013.

[16] M. Wacker and M. F. Holiack, "Vitamin D-effects on skeletal and extraskeletal health and the need for supplementation," Nutrients, vol. 5, no. 1, pp. 111-148, 2013.

[17] M. F. Holick, "Vitamin D deficiency," The New England Journal of Medicine, vol. 357, no. 3, pp. 266-281, 2007.

[18] M. F. Holick, N. C. Binkley, H. A. Bischoff-Ferrari et al., "Evaluation, treatment, and prevention of vitamin D deficiency: an endocrine society clinical practice guideline," The Journal of Clinical Endocrinology \& Metabolism, vol. 96, no. 7, pp. 19111930, 2011.

[19] Scientific Advisory Committee on Nutrition, Update on Vitamin $D$ Position statement by the Scientific Advisory Committee on Nutrition, The Stationery Office, London, UK, 2007.

[20] A. Mithal, D. A. Wahl, J.-P. Bonjour et al., "Global vitamin D status and determinants of hypovitaminosis D," Osteoporosis International, vol. 20, no. 11, pp. 1807-1820, 2009.

[21] S. G. Rostand, "Vitamin D deficiency in the pathogenesis of hypertension: still an unsettled question," Current Hypertension Reports, vol. 16, no. 8, article 464, 2014.

[22] R. Scragg, M. Sowers, and C. Bell, "Serum 25-hydroxyvitamin $\mathrm{D}$, ethnicity, and blood pressure in the third national health and nutrition examination survey," American Journal of Hypertension, vol. 20, no. 7, pp. 713-719, 2007.

[23] I. H. De Boer, R. Katz, M. Conchol et al., "Serum 25hydrocyvitamin D and change in estimated glomerular filtration rate," Clinical Journal of the American Society of Nephrology, vol. 6, pp. 2141-2149, 2011.

[24] D. E. Godar, S. J. Pope, W. B. Grant, and M. F. Holick, "Solar UV doses of adult Americans and vitamin $\mathrm{D}_{3}$ production," Dermato-Endocrinology, vol. 3, no. 4, pp. 243-250, 2011.

[25] S. G. Rostand, "Ultraviolet light may contribute to geographic and racial blood pressure differences," Hypertension, vol. 30, no. 2, pp. 150-156, 1997.

[26] L. A. Beveridge, A. D. Struthers, F. Khan et al., "effect of vitamin D supplementation on blood pressure: a systematic review and meta-analysis incorporating individual patient data," JAMA Internal Medicine, vol. 175, no. 5, pp. 745-754, 2015.

[27] J. P. Forman, J. B. Scott, K. Ng et al., "Effect of vitamin d supplementation on blood pressure in blacks," Hypertension, vol. 61, no. 4, pp. 779-785, 2013.

[28] Y. Dong, I. S. Stallmann-Jorgensen, N. K. Pollock et al., "A 16-week randomized clinical trial of 2000 international units daily vitamin $\mathrm{D}_{3}$ supplementation in black youth: 25Hydroxyvitamin D, adiposity, and arterial stiffness," Journal of Clinical Endocrinology and Metabolism, vol. 95, no. 10, pp. 45844591, 2010. 
[29] DO-HEALTH, "VitaminD3-Omega3-Home Exercise-Healthy Ageing and Longevity Trial," 2015, http://www.do-health.eu.

[30] T. D. O’Connell, J. E. Berry, A. K. Jarvis, M. J. Somerman, and R. U. Simpson, "1,25-Dihydroxyvitamin D3 regulation of cardiac myocyte proliferation and hypertrophy," The American Journal of Physiology, vol. 272, no. 4, part 2, pp. H1759-H1769, 1997.

[31] R. U. Simpson, "Selective knockout of the vitamin D receptor in the heart results in cardiac hypertrophy: is the heart a drugable target for vitamin D receptor agonists?" Circulation, vol. 124, no. 17, pp. 1808-1810, 2011.

[32] J. Wu, M. Garami, T. Cheng, and D. G. Gardner, "1,25 (OH $)_{2}$ vitamin $\mathrm{D}_{3}$ and retinoic acid antagonize endothelin-stimulated hypertrophy of neonatal rat cardiac myocytes," The Journal of Clinical Investigation, vol. 97, no. 7, pp. 1577-1588, 1996.

[33] W. Xiang, J. Kong, S. Chen et al., "Cardiac hypertrophy in vitamin D receptor knockout mice: role of the systemic and cardiac renin-angiotensin systems," American Journal of PhysiologyEndocrinology and Metabolism, vol. 288, no. 1, pp. E125-E132, 2005.

[34] A. Zittermann, S. S. Schleithoff, G. Tenderich, H. K. Berthold, R. Körfer, and P. Stehle, "Low vitamin D status: a contributing factor in the pathogenesis of congestive heart failure?" Journal of the American College of Cardiology, vol. 41, no. 1, pp. 105-112, 2003.

[35] A. J. van Ballegooijen, M. Visser, M. F. Cotch et al., "Serum vitamin $\mathrm{D}$ and parathyroid hormone in relation to cardiac structure and function: the ICELAND-MI substudy of AGESReykjavik," The Journal of Clinical Endocrinology \& Metabolism, vol. 98, no. 6, pp. 2544-2552, 2013.

[36] B. Kestenbaum, R. Katz, I. de Boer et al., "Vitamin D, parathyroid hormone, and cardiovascular events among older adults," Journal of the American College of Cardiology, vol. 58, no. 14, pp. 1433-1441, 2011.

[37] F. N. Saleh, H. Schirmer, J. Sundsfjord, and R. Jorde, "Parathyroid hormone and left ventricular hypertrophy," European Heart Journal, vol. 24, no. 22, pp. 2054-2060, 2003.

[38] S. A. Shedeed, "Vitamin D supplementation in infants with chronic congestive heart failure," Pediatric Cardiology, vol. 33, no. 5, pp. 713-719, 2012.

[39] S. S. Schleithoff, A. Zittermann, G. Tenderich, H. K. Berthold, P. Stehle, and R. Koerfer, "Vitamin D supplementation improves cytokine profiles in patients with congestive heart failure: a double-blind, randomized, placebo-controlled trial," American Journal of Clinical Nutrition, vol. 83, no. 4, pp. 754-759, 2006.

[40] I. Gotsman, A. Shauer, D. R. Zwas et al., "Vitamin D deficiency is a predictor of reduced survival in patients with heart failure; vitamin D supplementation improves outcome," European Journal of Heart Failure, vol. 14, no. 4, pp. 357-366, 2012.

[41] J. Thompson, R. Nitahpapand, P. Bhatti, and A. Kourliouros, "Vitamin D deficiency and atrial fibrillation," International Journal of Cardiology, vol. 184, pp. 159-162, 2015.

[42] L. Frost, S. P. Johnsen, L. Pedersen et al., "Seasonal variation in hospital discharge diagnosis of atrial fibrillation: a populationbased study," Epidemiology, vol. 13, no. 2, pp. 211-215, 2002.

[43] N. F. Murphy, S. Stewart, K. MacIntyre, S. Capewell, and J. J. V. McMurray, "Seasonal variation in morbidity and mortality related to atrial fibrillation," International Journal of Cardiology, vol. 97, no. 2, pp. 283-288, 2004.

[44] M. Rienstra, S. Cheng, M. G. Larson et al., "Vitamin D status is not related to development of atrial fibrillation in the community," American Heart Journal, vol. 162, no. 3, pp. 538541, 2011.
[45] F. Qayyum, N. L. Landex, B. R. Agner, M. Rasmussen, C. Jøns, and U. Dixen, "Vitamin D deficiency is unrelated to type of atrial fibrillation and its complications," Danish Medical Journal, vol. 59, no. 9, Article ID A4505, 2012.

[46] M. Demir, U. Uyan, and M. Melek, "The effects of vitamin D deficiency on atrial fibrillation," Clinical and Applied Thrombosis/Hemostasis, vol. 20, no. 1, pp. 98-103, 2014.

[47] W. R. Chen, Z. Y. Liu, Y. Shi et al., "Relation of low vitamin D to non valvular persistent atrial fibrillation in chinese patients," Annals of Noninvasive Electrocardiology, vol. 19, no. 2, pp. 166173, 2014.

[48] O. U. Ozcan, A. Gurlek, E. Gursoy, D. M. Gerede, and C. Erol, "Relation of vitamin D deficiency and new-onset atrial fibrillation among hypertensive patients," Journal of the American Society of Hypertension, vol. 9, no. 4, pp. 307-312, 2015.

[49] E. Kassi, C. Adamopoulos, E. K. Basdra, and A. G. Papavassiliou, "Role of vitamin D in atherosclerosis," Circulation, vol. 128, no. 23, pp. 2517-2531, 2013.

[50] G. N. Thomas, B. Ó. Hartaigh, J. A. Bosch et al., "Vitamin D levels predict all-cause and cardiovascular disease mortality in subjects with the metabolic syndrome: the Ludwigshafen risk and cardiovascular health (LURIC) study," Diabetes Care, vol. 35, no. 5, pp. 1158-1164, 2012.

[51] T. J. Wang, M. J. Pencina, S. L. Booth et al., "Vitamin D deficiency and risk of cardiovascular disease," Circulation, vol. 117, no. 4, pp. 503-511, 2008.

[52] F. Oz, A. Y. Cizgici, H. Oflaz et al., "Impact of vitamin D insufficiency on the epicardial coronary flow velocity and endothelial function," Coronary Artery Disease, vol. 24, no. 5, pp. 392-397, 2013.

[53] J. Y. Liew, S. R. Sasha, P. J. Ngu et al., "Circulating vitamin D levels are associated with the presence and severity of coronary artery disease but not peripheral arterial disease in patients undergoing coronary angiography," Nutrition, Metabolism and Cardiovascular Diseases, vol. 25, no. 3, pp. 274-279, 2015.

[54] J. A. Ford, G. S. MacLennan, A. Avenell et al., "Cardiovascular disease and vitamin D supplementation: trial analysis, systematic review, and meta-analysis," The American Journal of Clinical Nutrition, vol. 100, no. 3, pp. 746-755, 2014.

[55] M. B. Elamin, N. O. Abu Elnour, K. B. Elamin et al., "Vitamin $\mathrm{D}$ and cardiovascular outcomes: a systematic review and metaanalysis," The Journal of Clinical Endocrinology \& Metabolism, vol. 96, no. 7, pp. 1931-1942, 2011.

[56] S. E. Makariou, P. Michel, M. S. Tzoufi, A. Challa, and H. J. Milionis, "Vitamin D and stroke: promise for prevention and better outcome," Current Vascular Pharmacology, vol. 12, no. 1, pp. 117-124, 2014.

[57] S. Pilz, A. Tomaschitz, C. Drechsler, A. Zittermann, J. M. Dekker, and W. März, "Vitamin d supplementation: a promising approach for the prevention and treatment of strokes," Current Drug Targets, vol. 12, no. 1, pp. 88-96, 2011.

[58] P. Brøndum-Jacobsen, B. G. Nordestgaard, P. Schnohr, and M. Benn, "25-Hydroxyvitamin D and symptomatic ischemic stroke: an original study and meta-analysis," Annals of Neurology, vol. 73, no. 1, pp. 38-47, 2013.

[59] M. D. Witham, F. J. Dove, J. A. Sugden, A. S. Doney, and A. D. Struthers, "The effect of vitamin D replacement on markers of vascular health in stroke patients-a randomised controlled trial," Nutrition, Metabolism and Cardiovascular Diseases, vol. 22, no. 10, pp. 864-870, 2012. 
[60] J. Hsia, G. Heiss, H. Ren et al., "Calcium/vitamin D supplementation and cardiovascular events," Circulation, vol. 115, no. 7, pp. 846-854, 2007.

[61] A. Avenell, G. S. MacLennan, D. J. Jenkinson et al., "Long-term follow-up for mortality and cancer in a randomized placebocontrolled trial of vitamin $\mathrm{D}_{3}$ and/or calcium (RECORD Trial)," Journal of Clinical Endocrinology and Metabolism, vol. 97, no. 2, pp. 614-622, 2012.

[62] D. P. Trivedi, R. Doll, and K. T. Khaw, "Effect of four monthly oral vitamin $\mathrm{D}_{3}$ (cholecalciferol) supplementation on fractures and mortality in men and women living in the community: randomised double blind controlled trial," British Medical Journal, vol. 326, article 469, 2003.

[63] J. L. Anderson, H. T. May, B. D. Horne et al., "Relation of vitamin $\mathrm{D}$ deficiency to cardiovascular risk factors, disease status, and incident events in a general healthcare population," American Journal of Cardiology, vol. 106, no. 7, pp. 963-968, 2010.

[64] M. L. Melamed, P. Muntner, E. D. Michos et al., "Serum 25-hydroxyvitamin D levels and the prevalence of peripheral arterial disease results from NHANES 2001 to 2004," Arteriosclerosis, Thrombosis, and Vascular Biology, vol. 28, no. 6, pp. 1179-1185, 2008.

[65] A. Fahrleitner, H. Dobnig, A. Obernosterer et al., "Vitamin D deficiency and secondary hyperparathyroidism are common complications in patients with peripheral arterial disease," Journal of General Internal Medicine, vol. 17, no. 9, pp. 663-669, 2002.

[66] E. Gouveri, N. Papanas, A. I. Hatzitolios, and E. Maltezos, "Hypovitaminosis D and peripheral arterial disease: emerging link beyond cardiovascular risk factors," European Journal of Internal Medicine, vol. 23, no. 8, pp. 674-681, 2012.

[67] M. M. McDermott, K. Liu, L. Ferrucci et al., "Vitamin D status, functional decline, and mortality in peripheral artery disease," Vascular Medicine, vol. 19, no. 1, pp. 18-26, 2014.

[68] A. Zittermann, S. Iodice, S. Pilz, W. B. Grant, V. Bagnardi, and S. Gandini, "Vitamin D deficiency and mortality risk in the general population: a meta-analysis of prospective cohort studies," American Journal of Clinical Nutrition, vol. 95, no. 1, pp. 91-100, 2012.

[69] H. Johansson, A. Odén, J. Kanis et al., "Low serum vitamin D is associated with increased mortality in elderly men: MrOS Sweden," Osteoporosis International, vol. 23, no. 3, pp. 991-999, 2012.

[70] M. B. Elamin, N. O. Abu Elnour, K. B. Elamin et al., "Vitamin $\mathrm{D}$ and cardiovascular outcomes: a systematic review and metaanalysis," Journal of Clinical Endocrinology and Metabolism, vol. 96, no. 7, pp. 1931-1942, 2011.

[71] L. Rejnmark, A. Avenell, T. Masud et al., "Vitamin D with calcium reduces mortality: patient level pooled analysis of 70,528 patients from eight major vitamin D trials," Journal of Clinical Endocrinology and Metabolism, vol. 97, no. 8, pp. 26702681, 2012.

[72] G. Bjelakovic, L. L. Gluud, D. Nikolova et al., "Vitamin D supplementation for prevention of mortality in adults," The Cochrane Database of Systematic Reviews, vol. 10, no. 1, Article ID CD007470, 2014.

[73] M. F. Holick, R. M. Biancuzzo, T. C. Chen et al., "Vitamin $\mathrm{D}_{2}$ is as effective as vitamin $\mathrm{D}_{3}$ in maintaining circulating concentrations of 25-hydroxyvitamin D," The Journal of Clinical Endocrinology \& Metabolism, vol. 93, no. 3, pp. 677-681, 2008.

[74] A. C. Ross, J. E. Manson, S. A. Abrams et al., “The 2011 report on dietary reference intakes for calcium and vitamin $\mathrm{D}$ from the Institute of Medicine: what clinicians need to know," Journal of Clinical Endocrinology and Metabolism, vol. 96, no. 1, pp. 5358, 2011.

[75] P. Pramyothin and M. F. Holick, "Vitamin D supplementation: guidelines and evidence for subclinical deficiency," Current Opinion in Gastroenterology, vol. 28, no. 2, pp. 139-150, 2012.

[76] Publich Health England, Vitamin D; Information for Healthcare Professionals, Publich Health England, London, UK, 2014.

[77] European Food Safety Authority, Tolerable Upper Intake Levels for Vitamins and Minerals, EFSA, 2006.

[78] R. Vieth, "Vitamin D toxicity, policy, and science," Journal of Bone and Mineral Research, vol. 22, supplement 2, pp. V64-V68, 2007.

[79] M. L. Melamed, E. D. Michos, W. Post, and B. Astor, "25hydroxyvitamin D levels and the risk of mortality in the general population," Archives of Internal Medicine, vol. 168, no. 15, pp. 1629-1637, 2008.

[80] National Institute for Health and Care Excellence, "Vitamin D: increasing supplement use among at-risk groups," NICE Public Health Guidance 56, NICE, London, UK, 2014. 


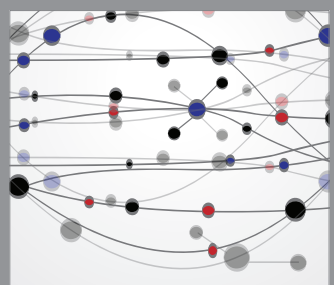

The Scientific World Journal
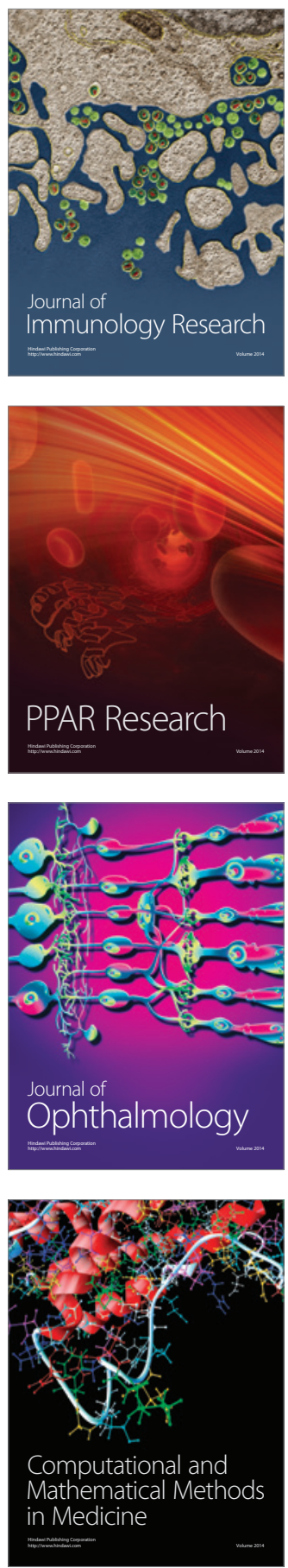

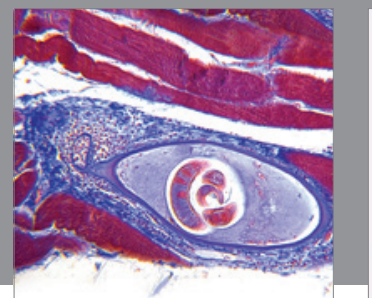

Gastroenterology

Research and Practice
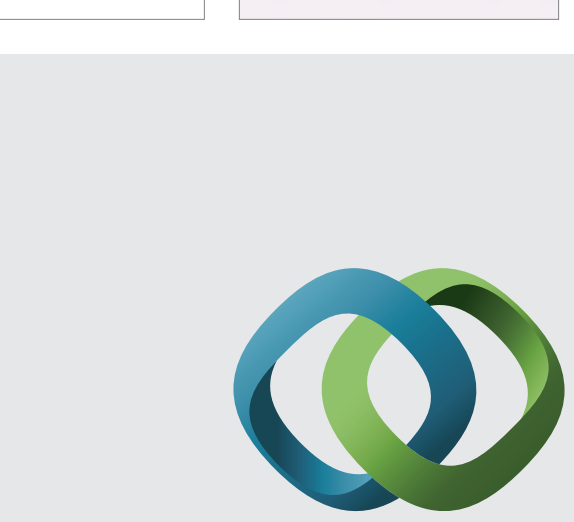

\section{Hindawi}

Submit your manuscripts at

http://www.hindawi.com
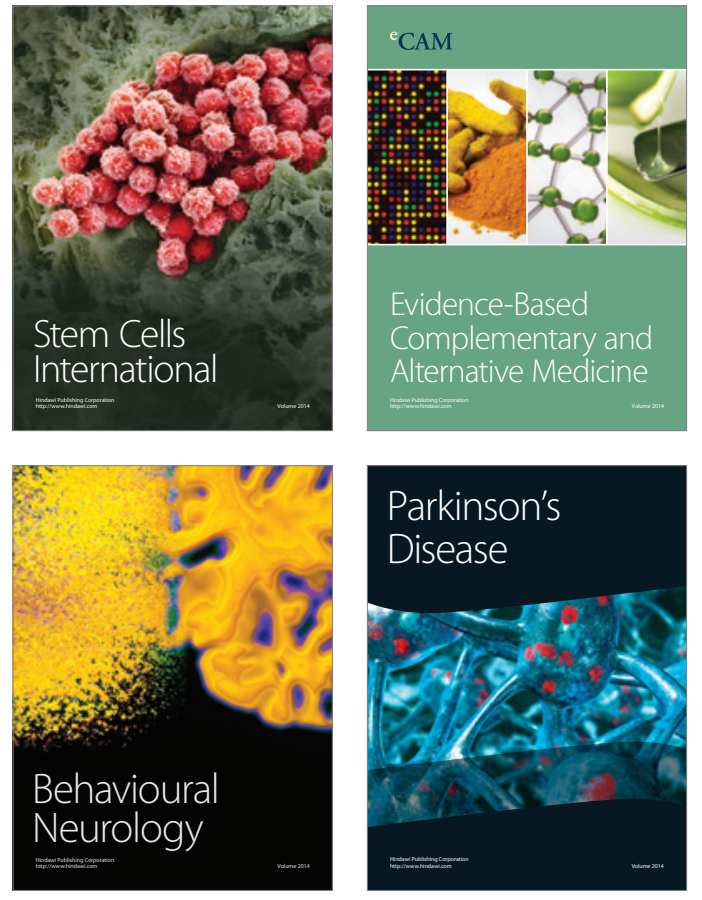
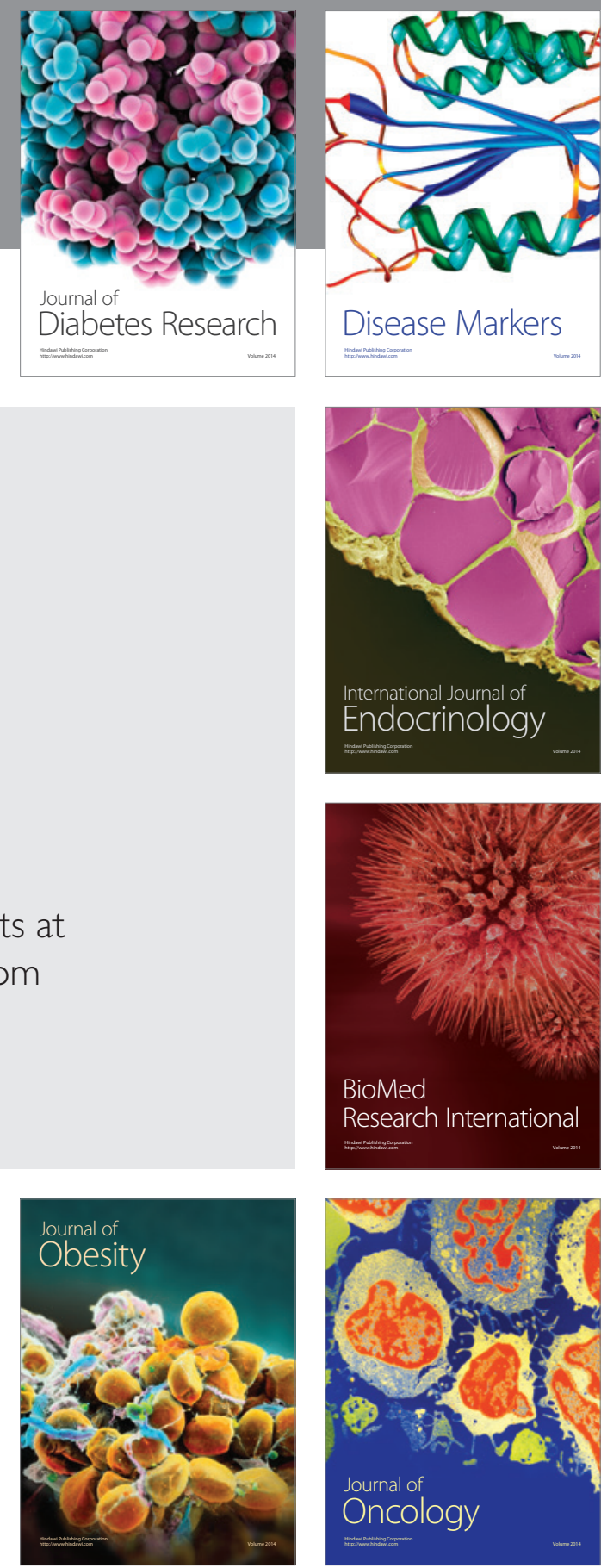

Disease Markers
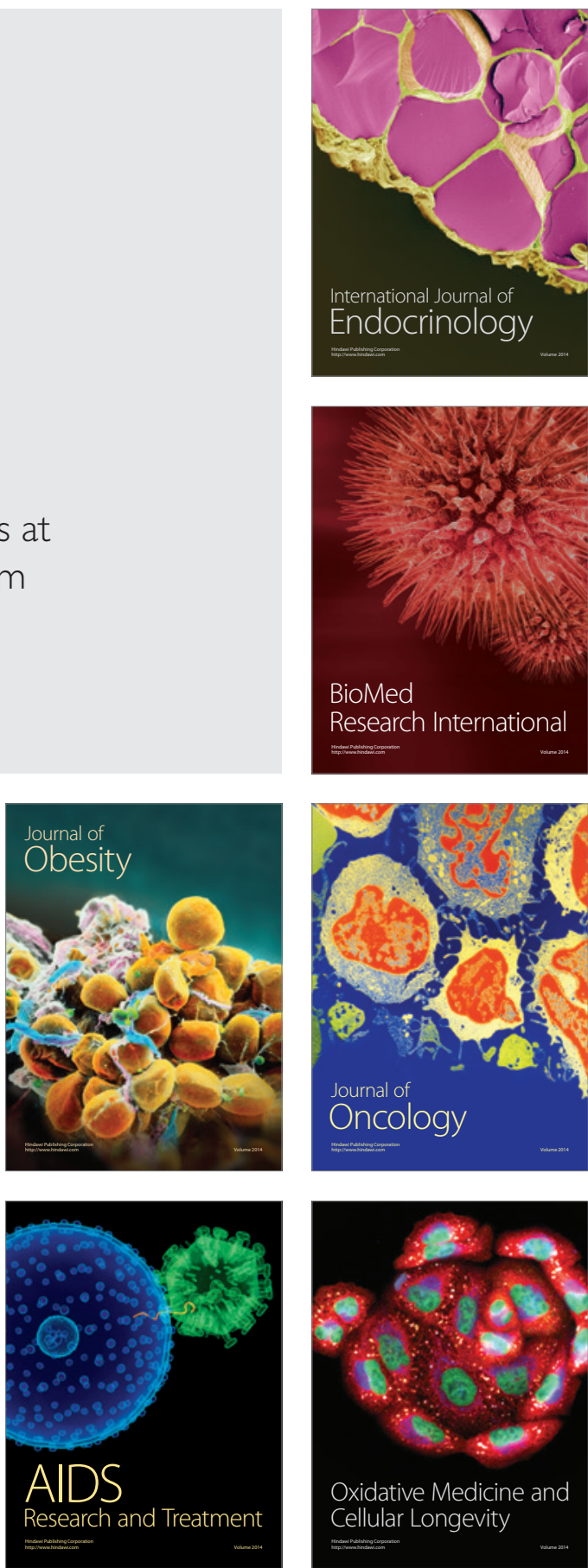